\title{
Machine learning techniques in cardiac risk assessment
}

\author{
Makine öğrenmesi teknikleriyle kardiyak risk değerlendirmesi \\ Elif Kartal ${ }^{1}$, Mehmet Erdal Balaban $\mathbb{1}^{2}$ \\ Institution where the research was done: \\ istanbul University, İstanbul, Turkey \\ Author Affiliations: \\ 'Informatics Department, İstanbul University, ístanbul, Turkey \\ ${ }^{2}$ Turkish Community Services Foundation (TOVAK), İstanbul, Turkey
}

\begin{abstract}
Background: The objective of this study was to predict the mortality risk of patients during or shortly after cardiac surgery by using machine learning techniques and their learning abilities from collected data.

Methods: The dataset was obtained from Acıbadem Maslak Hospital. Risk factors of the European System for Cardiac Operative Risk Evaluation (EuroSCORE) were used to predict mortality risk. First, Standard EuroSCORE scores of patients were calculated and risk groups were determined, because 30-day follow-up information of patients was not available in the dataset. Models were created with five different machine learning algorithms and two different datasets including age, serum creatinine, left ventricular dysfunction, and pulmonary hypertension were numeric in Dataset 1 and categorical in Dataset 2. Model performance evaluation was performed with 10-fold cross-validation.

Results: Data analysis and performance evaluation were performed with R, RStudio and Shiny. C4.5 was selected as the best algorithm for risk prediction (accuracy $=0.989$ ) in Dataset 1 . This model indicated that pulmonary hypertension, recent myocardial infarct, surgery on thoracic aorta are the primary three risk factors that affect the mortality risk of patients during or shortly after cardiac surgery. Also, this model is used to develop a dynamic web application which is also accessible from mobile devices (https://elifkartal.shinyapps.io/euSCR/).

Conclusion: The $\mathrm{C} 4.5$ decision tree model was identified as having the highest performance in Dataset 1 in predicting the mortality risk of patients. Using the numerical values of the risk factors can be useful in increasing the performance of machine learning models. Development of hospital-specific local assessment systems using hospital data, such as the application in this study, would be beneficial for both patients and doctors.
\end{abstract}

Keywords: Cardiology; machine learning; risk assessment.

\section{$\ddot{O} Z$}

Amaç: Bu çalışmada amaç; makine öğrenmesi tekniklerini ve bu tekniklerin veriden öğrenme yeteneğini kullanarak kalp ameliyat1 sırasında ya da kalp ameliyatı geçirdikten kısa bir süre sonra hastanın mortalite riskini öngörebilmektir.

Çalışma planı: Veri seti Acıbadem Maslak Hastanesi'nden temin edildi. European System for Cardiac Operative Risk Evaluation (EuroSCORE) risk faktörleri, mortalite riskini tahmin etmek için kullanıldı. Hastaların 30 günlük takip bilgileri veri setinde mevcut olmadığından çalışmada ilk olarak Standart EuroSCORE puanları hesaplandı ve risk grupları belirlendi. Modeller; beş farklı makine öğrenmesi algoritması ile yaş, serum kreatinin, sol ventrikül disfonksiyonu ve pulmoner hipertansiyonun Dataset 1'de sayısal, Dataset 2'de kategorik olduğu iki farklı veri kümesiyle oluşturuldu. Model performans değerlendirmesi, 10-kat çapraz geçerleme ile yapild 1 .

Bulgular: Veri analizi ve performans değerlendirmesi R, RStudio ve Shiny ile gerçekleştirildi. C4.5 algoritmasıyla Dataset 1 üzerinde kurulan model risk tahmini için en iyi model olarak seçildi (doğruluk= 0.989). Bu model; pulmoner hipertansiyon, geçirilmiş miyokard enfarktüsü ve torasik aort cerrahisi niteliklerini bir hastanın mortalite riskini etkileyen ilk üç risk faktörü olduğuna işaret etmektedir. Ayrıca, bu model mobil cihazlardan da erişilebilen dinamik bir web uygulaması geliştirmek için kullanıldı (https://elifkartal.shinyapps.io/euSCR/).

Sonuç: Bir hastanın mortalite riskini öngörebilmede C4.5 karar ağacı modeli, kullanılan veri seti olan Dataset 1'de en iyi performansa sahip bir model olduğu belirlendi. Risk faktörlerinin sayısal değerlerini kullanmak, makine öğrenmesi modellerinin performansını artırmada yararlı olabilir. Bu çalışmadaki uygulamada olduğu gibi hastaneye özgü veri kullanılarak yerel değerlendirme sistemlerinin geliştirilmesi hem hastalar hem de doktorlar için yararlı olabilecektir.

Anahtar sözcükler: Kardiyoloji; makine öğrenmesi; risk değerlendirmesi.

Received: November 14, 2017 Accepted: May 23, 2018

Correspondence: Elif Kartal. İstanbul Üniversitesi Enformatik Bölümü, 34134 Fatih, İstanbul, Turkey.

Tel: +90 212-4400000 / 11545 e-mail: elifk@istanbul.edu.tr

Cite this article as:

Kartal E, Balaban ME. Machine learning techniques in cardiac risk assessment. Turk Gogus Kalp Dama 2018;26(3):394-401. 
For many years, researchers have focused on improving life expectancy of patients and their quality of life, therefore, the treatment of common diseases has become a top priority for governments. According to the World Health Organization ${ }^{[1]}$ cardiovascular diseases (CVD) are the top cause of all deaths around the world. According to the American Heart Association ${ }^{[2]}$ one of every three deaths in the United States were caused by CVD which is a top killer both in the United States and worldwide. In this regard, Turkey has a similar situation as the United States. The Turkish Statistical Institute ${ }^{[3]}$ indicates that $40.1 \%$ of all deaths in 2015 and $39.8 \%$ of all deaths in 2016 in Turkey were from circulatory system diseases. Statistics also show that ischemic heart disease, cerebrovascular diseases, hypertensive diseases, and other heart diseases accounted for $40.5 \%$, $23.6 \%, 8.8 \%$, and $22.3 \%$ of deaths due to circulatory system diseases, respectively, in $2016 .^{[3]}$ One way to prevent and control death caused by CVD is to predict the patient's mortality risk.

Risk grouping and forecasting models are seen as essential tools for assessing the quality of care, medical decision making, patient counseling, and patient consent. ${ }^{[4]}$ Different risk stratification models such as the Parsonnet Scoring System, Cleveland Clinic Scoring System, The Society of Thoracic Surgeons National Database Risk Scoring System, etc. are developed to evaluate the results of open-cardiac surgery. ${ }^{[5]}$ Geissler et al. ${ }^{[6]}$ compared six different scoring techniques and reported that the European System for Cardiac Operative Risk Evaluation (EuroSCORE) gave the best performance of mortality prediction. Dişcigil et al. ${ }^{[7]}$ pointed out that the EuroSCORE has only four factors related to surgery, therefore it is the least affected by surgery factors. In this regard, increasing patient based risk assessment and minimizing differences which may arise due to the surgical team are seen advantages of EuroSCORE. ${ }^{[6,7]}$ In addition, a system based on EuroSCORE called Cardiac Risk Scoring is used by hospitals in Turkey ${ }^{[8]}$ and hospital charges are determined according to this risk score. Karabulut et al. ${ }^{[9]}$ found that EuroSCORE is easy and applicable for the cardiovascular surgery clinic; although multi-centered studies and increasing the number of observations would increase the validity of the system in Turkey.

\section{European system for cardiac operative risk evaluation}

EuroSCORE is a scoring system which was developed to predict early death in cardiac surgery patients. ${ }^{[10-12]}$ Roques et al. ${ }^{[13]}$ identified risk factors for mortality in cardiac surgical adult patients as part of EuroSCORE's development process. Also a large portion of this study's database was used to develop the EuroSOCRE. Ninety-seven risk factors were collected from 20 thousand patients from 128 hospitals of eight European countries; however only 17 of these risk factors (Table 1) were selected for the scoring system as significant, reliable, and objective. ${ }^{[10]}$ Today, there are three EuroSCORE models that provides online risk calculations: Standard (Additive) EuroSCORE, ${ }^{[14]}$ Logistic EuroSCORE, ${ }^{[15]}$ and EuroSCORE II $^{[16]}$ (Figure 1):

\section{Machine learning in cardiac risk assessment}

The machine learning field is associated with building automatically developed computer programs with experience. ${ }^{[17]}$ Machine learning incorporates computer programming using sample data or past experience for performance optimization. ${ }^{[18]}$ Simon $^{[19]}$ described learning as any change that would improve a system's second performance on the same task or in a new task related to the same population. Mitchell ${ }^{[17]}$ stated how a machine can change its behavior in order to learn by taking performance into consideration: "A computer program is said to learn from experience (E) with respect to some class of tasks (T) and performance measure $(P)$, if its performance at tasks in $(T)$, as measured by $(P)$, improves with experience $(E)$ ".

\section{Table 1. The European system for cardiac operative risk evaluation risk factors}

\begin{tabular}{ll} 
Patient-related factors \\
1 & Age \\
2 & Gender \\
3 & Chronic pulmonary disease \\
4 & Extracardiac arteriopathy \\
5 & Neurological dysfunction disease \\
6 & Previous cardiac surgery \\
7 & Serum creatinine \\
8 & Active endocarditis \\
9 & Critical preoperative state \\
Cardiac-related factors \\
10 & Unstable angina \\
11 & Left ventricular dysfunction \\
12 & Recent myocardial infarct \\
13 & Pulmonary hypertension \\
Operation-related factors \\
14 & Emergency \\
15 & Other than isolated coronary artery bypass grafting \\
16 & Surgery on thoracic aorta \\
17 & Post-infarct septal rupture \\
\hline &
\end{tabular}



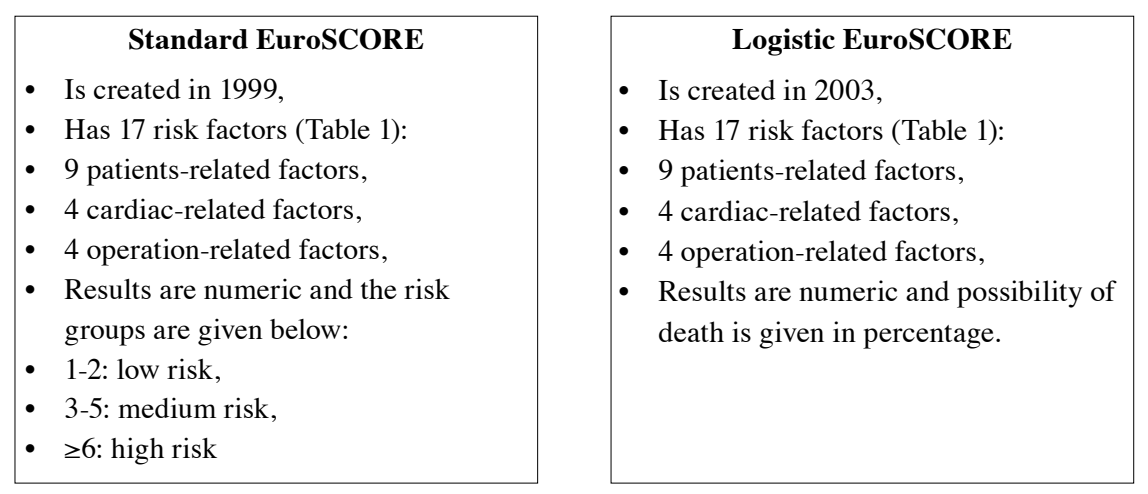

\begin{tabular}{|l|}
\hline \multicolumn{1}{|c|}{ EuroSCORE II } \\
- Is created in 2011, \\
- Has 18 risk factors: \\
- 5 cardients-related factors, \\
- 3 operation-related factors, \\
- Results are numeric and possibility of \\
death is given in percentage. \\
\\
\end{tabular}

Figure 1. Comparison of EuroSCORE models.

There are two main types of learning: supervised learning and unsupervised learning. Supervised learning is a form of learning in which the learner receives a set of labeled examples of training data and makes predictions for points that it has not seen before. ${ }^{[20]}$ Unsupervised learning is a form of learning in which no labeled sample is found in the learners' training data. ${ }^{[20]}$ The main difference between supervised and unsupervised learning is the presence of the target attribute in the dataset.

Both machine learning and common scoring systems have been used for predicting mortality risk after cardiac surgery. Nouei et al. ${ }^{[21]}$ proposed the Lookup Genetic Fuzzy Annealing System to predict mortality risk after coronary artery bypass grafting (CABG) surgery and compared its accuracy $(\mathrm{acc}=0.853)$ with two well-known machine learning techniques: logistic regression $(\mathrm{acc}=0.781)$ and the multilayer perceptron neural network $(\mathrm{acc}=0.748)$. Tu et al. ${ }^{[22]}$ compared the performance of the artificial neural networks and logistic regression to estimate the mortality risk in the hospital after CABG operation, and found that the two methods reported similar relationships between patient characteristics and mortality. Lippmann et al. ${ }^{[23]}$ estimated the mortality risk of death, stroke, and renal impairment for patients who underwent CABG operation using artificial neural networks. Tunca $^{[24]}$ developed a risk prediction model by using the REMARC (Risk Estimation by Maximizing Area under Receiver Operating Characteristic Curve) algorithm and TurkoSCORE system which involves a database and learning system to estimate mortality risk for patients in Turkey.

This study aimed to predict the mortality risk of patients during or shortly after cardiac surgery by using EuroSCORE mortality risk factors and machine learning techniques.

\section{MATERIAL AND METHODS}

In this study, CRoss-Industry Standard Process for Data Mining (CRISP-DM) was chosen to systematically perform machine learning analyses. The CRISP-DM model was developed with the participation of industry leaders with input from over two hundred experts and data mining tool and service providers. ${ }^{[25]}$ It consists of six stages: Business Understanding, Data Understanding, Data Preparation, Modeling, Evaluation, and Deployment. The study's method is explained in terms of CRISP-DM below. In this study, approval of local committee of Acıbadem Maslak Hospital was obtained.

\section{Business understanding}

Business understanding is defined as problem understanding in the business environment. In this study, business understanding was considered to be problem understanding. The problem was defined as predicting the risk assessment of patients during or shortly after cardiac surgery.

\section{Data understanding}

In this study, data was obtained from Acıbadem Maslak Hospital. Initially, the dataset consisted of 17 predictive attributes (Table 1). The total number of observations was 1482. Dead / alive status of patients was determined by Roques et al. ${ }^{[13]}$ according to the next 30 days after surgery. However, when the date of operation and discharge from hospital were examined in this study, a standard 30-day postoperative followup period could not be obtained. Therefore, patients were grouped according to standard EuroSCORE scores: low (0-2 points), moderate (3-5 points), and high ( $\geq 6$ point). This attribute was also used as a target attribute for machine learning algorithms in the analyses. 


\section{Data preparation}

A large number of missing values were detected. While the standard and logistic EuroSCORE calculator $^{[26]}$ does not have any option for missing values, the calculator was designed for patients ${ }^{[27]}$ to have options of "Do not know" and "No", and the calculated scores was equal in both cases. Therefore, in this study, it was decided to complete the missing values in the dataset before the analyses. Missing values of the categorical and numerical attributes were completed with the most repeated category and the mean of the each attribute in terms of each risk group (class label of the target attribute).

Outliers were detected and removed from the dataset by considering the rules provided by experts. Since the post-infarct septal rupture attribute was only seen in one patient, it was removed from the dataset. Duplicated observations were also removed.

EuroSCORE only works with categorical attributes; however numerical values of age, serum creatinine, left ventricular dysfunction, and pulmonary hypertension attributes were also available in the dataset. It is believed that possible effects of different data types of these attributes can be examined. Therefore, analyses are performed on two different datasets in which the attributes are numerical in Dataset 1 and categorical in Dataset 2. The numerical attributes in Dataset 1 were normalized using the max-min normalization technique. ${ }^{[28]}$ Table 2 shows the frequency distribution of risk groups in Dataset 1 and Dataset 2.

\section{Modeling}

Alternative models were created with Naive Bayes classifier, k-nearest neighbor algorithm, logistic regression analysis, ID3, and $\mathrm{C} 4.5$ decision tree algorithms to predict the mortality risk of patients during or shortly after cardiac surgery. The basic concepts of these algorithms are briefly explained below. ${ }^{[17,28-30]}$

Naive Bayes Classifier: An easily understandable method which makes use of the Bayes Theorem. Probabilities of an observation belonging to the class

Table 2. Frequency distribution of risk groups in the datasets

\begin{tabular}{lcccc}
\hline & \multicolumn{4}{c}{ Target attribute (risk) } \\
\cline { 2 - 5 } & Low & Medium & High & Total \\
\hline Dataset 1 & 441 & 538 & 486 & 1465 \\
Dataset 2 & 18 & 110 & 294 & 422 \\
\hline
\end{tabular}

labels of the target attribute can be found with this method. Maximum a posteriori hypothesis and assumption of class conditional independence are two key elements that are used in classification process.

K-Nearest Neighbor Algorithm: The distance is calculated between the unlabeled observation and all observations in the dataset. k-observations are taken with smallest distance value. The most frequent class in $\mathrm{k}$ observations is assigned as the class value.

In this study, $\mathrm{k}$ parameter of the algorithm was initially selected. In order to obtain the best $\mathrm{k}$, the algorithm was applied for $\mathrm{k}=1,2, \ldots, 10$. Furthermore, Gower distance ${ }^{[31]}$ was preferred for Dataset 1 since it has both binary coded and numerical attributes, Jaccard distance ${ }^{[32]}$ is used for Dataset 2 because the attributes in Dataset 2 are encoded in asymmetric binary format. Moreover, the function which allows the Gower distance for the algorithm is developed with $\mathrm{R}$ by the authors for the analyses.

Logistic Regression Analysis: Provides the relationship between the predictive attributes and the target attribute if the target attribute is categorical. It is defined as binary, ordinal, and multinomial logistic regression according to data type of the target attribute. ${ }^{[33]}$

In this study, due to the number of zero frequency cells, some categories of the attributes (including age, left ventricular dysfunction, and the target attribute) were merged to make the data more appropriate for the analyses and binary logistic regression was performed. The purpose of binary logistic regression is to estimate the possibility that the target attribute gets 1 value when 1 code is used for the risky situation in the target attribute. ${ }^{[33]}$

ID3 and C4.5 Decision Tree Algorithms: ID3 is one of the simplest decision tree algorithms. It uses entropy and information gain to measure how well the training samples are split. The information gain criterion used in the ID3 has left its place to gain ratio in C4.5 which applies a kind of normalization called split information to information gain. Since C4.5 can work with attributes that take both categorical and numerical values and ID3 works only with categorical attributes, in this study analysis was performed with C4.5 on Dataset 1 and with ID3 on Dataset 2.

\section{Evaluation}

Various methods have been developed for model performance evaluation such as hold-out, stratified sampling, three-way split, cross-validation, etc. 
Table 3. Top three attributes according to contribution level of the models

\begin{tabular}{|c|c|c|c|c|}
\hline & $\mathrm{C} 4.5$ & ID3 & Logistic regression analysis & Logistic regression analysis \\
\hline & Dataset 1 & Dataset 2 & Dataset 1 & Dataset 2 \\
\hline 1 & Pulmonary hypertension* & Recent myocardial infarct & Pulmonary hypertension & Surgery on thoracic aorta \\
\hline 2 & Recent myocardial infarct & Other than isolated CABG & Age & Critical preoperative state \\
\hline 3 & Surgery on thoracic aorta & Age & Previous cardiac surgery & Recent myocardial infarct \\
\hline
\end{tabular}

* It is thought that the initial presence of a large number of missing values of pulmonary hypertension has an effect on the obtained result; CABG: Coronary artery bypass grafting.

In this study, stratified 10 -fold cross validation method was chosen to compare performance of the models. In $\mathrm{k}$-fold cross-validation, the dataset is divided into $\mathrm{k}$-equal parts. One part is used for testing, and remaining k-1 parts are used for training. In the end, $\mathrm{k}$ error rates (or other performance evaluation measures) are obtained and average of the errors are taken into account as performance.

In addition; various measures can be used for model performance evaluation. ${ }^{[34]}$ In this study, accuracy, error, and also more comprehensive measures such as F-measure and diagnostic odds ratio were calculated.

Analyses were performed with $\mathrm{R}$ programming language and RStudio. $\mathrm{R}$ is a free language and environment that allows statistical calculations and graphical visualization. ${ }^{[35]}$ RStudio $^{[36]}$ is an integrated development environment for R. Various R packages such as e1071,,$^{[37]}$ knnGarden, ${ }^{[38]}$ RWeka,,${ }^{[39,40]}$ shiny, ${ }^{[41]}$ and shinythemes ${ }^{[42]}$ are used to perform analyses in R. A dynamic web application of the best model has been developed with Shiny ${ }^{[43]}$ and it provides the development of applications that enable the transfer of $\mathrm{R}$ codes to the web environment. One of the ways to share these applications on the web is to publish it from shinyapps.io..$^{[44]}$

\section{RESULTS}

Considering that both categorical and numerical attributes were used in Dataset $1 \mathrm{C} 4.5$ decision tree algorithm performed the best in risk prediction $(\mathrm{acc}=0.989)$. This algorithm was followed by logistic regression analysis $(\mathrm{acc}=0.982)$, Naive Bayes classifier $(\mathrm{acc}=0.977)$, and k-nearest neighbor algorithm $($ acc $=0.972)$. However, model performances when working with only categorical attributes (Dataset 2) were lower than Dataset 1.

The ranking of the attributes in terms of contribution levels to models are obtained from ID3, C4.5, and logistic regression analysis (Table 3 ).

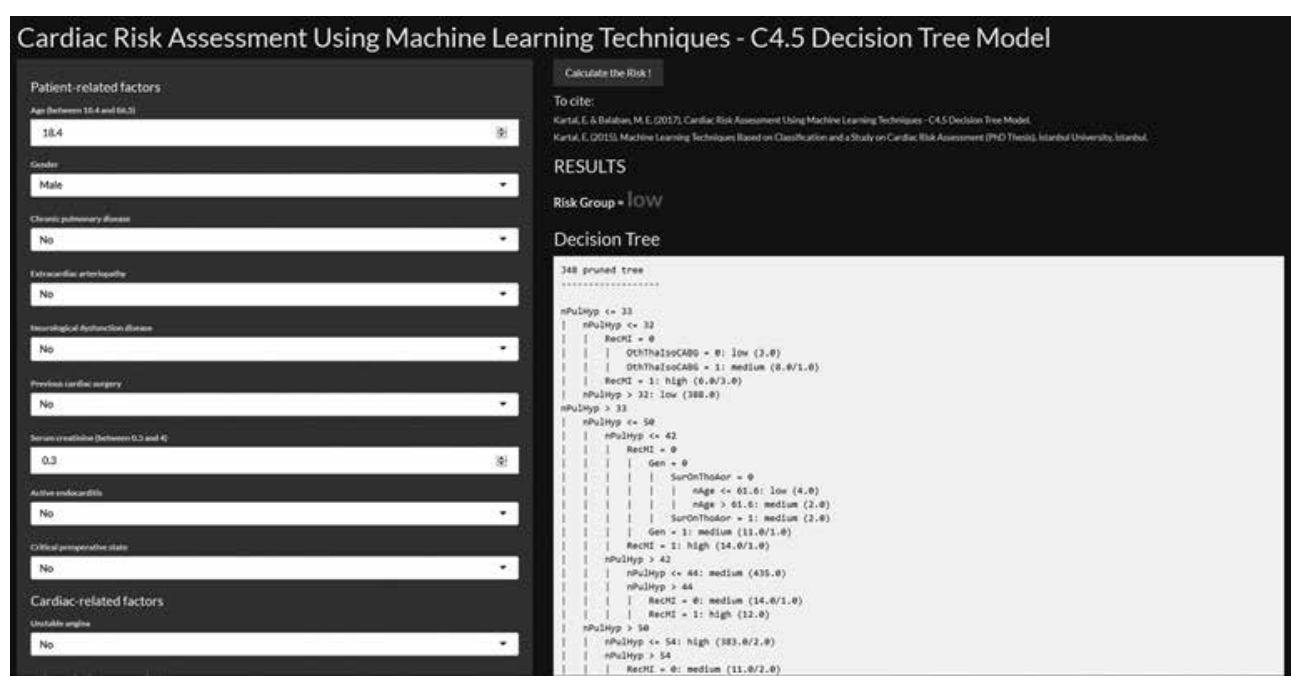

Figure 2. Web application for cardiac risk assessment using the $\mathrm{C} 4.5$ decision tree model. 
Table 4. Results of model performance evaluation

\begin{tabular}{|c|c|c|c|c|c|c|c|c|}
\hline & \multicolumn{4}{|c|}{ Dataset 1} & \multicolumn{4}{|c|}{ Dataset 2} \\
\hline & Accuracy & $\begin{array}{l}\text { Diagnostic } \\
\text { Odds Ratio }\end{array}$ & F-Measure & Error & Accuracy & $\begin{array}{l}\text { Diagnostic } \\
\text { Odds Ratio }\end{array}$ & F-Measure & Error \\
\hline $\begin{array}{l}\text { Naive Bayes } \\
\text { Classifier }\end{array}$ & 0.977 & 6910.236 & 0.966 & 0.023 & 0.913 & 122.848 & 0.870 & 0.087 \\
\hline k-Nearest & \multicolumn{4}{|c|}{$\mathrm{k}=5$} & \multicolumn{4}{|c|}{$\mathrm{k}=9$} \\
\hline Neighbor & 0.972 & 1884.235 & 0.958 & 0.028 & 0.886 & 69.997 & 0.830 & 0.114 \\
\hline Algorithm & 0.982 & Infinity & 0.973 & 0.018 & 0.898 & Infinity & 0.926 & 0.102 \\
\hline Decision Tree & \multicolumn{4}{|c|}{$\mathrm{C} 4.5$} & \multicolumn{4}{|c|}{ ID3 } \\
\hline Algorithms & 0.989 & Infinity & 0.984 & 0.011 & 0.840 & 35.213 & 0.761 & 0.160 \\
\hline
\end{tabular}

\section{Deployment}

C4.5 decision tree model, which gives the best performance in Dataset 1, was integrated into a dynamic web application which is also accessible from mobile devices (https://elifkartal.shinyapps.io/euSCR/) (Figure 2). It is possible to produce rules similar to those below by using the decision tree.

- IF pulmonary hypertension is less than or equal to 32 and recent myocardial infarct $=\mathrm{NO}$ and Other than isolated $\mathrm{CABG}=\mathrm{NO}$; Then the RISK is LOW

- IF pulmonary hypertension is less than or equal to 32 and recent myocardial infarct $=\mathrm{NO}$ and Other than isolated $\mathrm{CABG}=\mathrm{YES}$; Then the RISK is MEDIUM

- IF pulmonary hypertension is greater than 33 and pulmonary hypertension is less than or equal to 42 and recent myocardial infarct= YES; Then the RISK is HIGH.

\section{DISCUSSION}

This study aimed to determine the mortality risk of a patient during or shortly after cardiac surgery by using machine learning techniques. This study differs from other studies by using EuroSCORE in the literature in following aspects:

- Since there was no 30-day follow-up data for patients in the dataset as in EuroSCORE, the standard EuroSCORE scores of the patients were first calculated and predictions were made using the risk groups as target attribute. Seventeen risk factors were used in the calculation of Standard EuroSCORE; however since postinfarct septal rupture attribute was only seen in one patient, this attribute was not used in analyses.
- In EuroSCORE, if the patient did not know the exact value of the risk factor, the factor was calculated as absent. However, in this study, the missing values of the remaining 16 risk factors were completed.

- Numerical and categorical values of age, serum creatinine, left ventricular dysfunction, and pulmonary hypertension attributes were used in Dataset 1 and Dataset 2, respectively.

- Not only accuracy and error, but more comprehensive performance evaluation measures were also used.

The highest performance was obtained from the C4.5 decision tree algorithm model in Dataset 1 and the lowest performance was obtained from the ID3 decision tree algorithm in Dataset 2.

It was determined that the performance measures obtained from Dataset 2 were significantly lower than the values obtained from Dataset 1 . The general evaluation showed that the errors in Table 4 ranged from 0.011 to 0.160 . The difference between these error values could be considered insignificant for another application domain; however it is thought that since the patient's mortality risk is highly crucial, it is suggested to use the numerical values of the factors that affect the target attribute.

Sixteen attributes were ordered with the help of ID3 and C4.5 decision tree algorithms and logistic regression analysis. Pulmonary hypertension was first rank in models derived from Dataset 1. It was also determined that age factor was in the top three for two different machine learning algorithms.

\section{Conclusion}

The C4.5 decision tree model had the highest performance in predicting the mortality risk of patients 
(accuracy $=0.989)$. This model can be accepted as a predictor model based on learning from data from this study. Using numerical values of the risk factors may be useful in increasing the performance of machine learning models. Developing hospital-specific local assessment systems, such as the application in this study, would be beneficial for both patients and doctors. Furthermore, this model should be tested with datasets collected from other hospitals.

\section{Acknowledgement}

This study was formed within the scope of "Kartal E. (2015). Machine Learning Techniques Based on Classification and a Study on Cardiac Risk Assessment (PhD Thesis). İstanbul University, İstanbul".

The authors would like to thank to Acrbadem Maslak Hospital Chief Physician Prof. Dr. Çağlar Çuhadaroğlu, Acıbadem University School of Medicine Head of Department of Cardiovascular Surgery Prof. Dr. Cem Alhan, and Acibadem Maslak Hospital Cardiovascular Surgery Department Assistant Sevinç Kocaman who provided the dataset.

\section{Declaration of conflicting interests}

The authors declared no conflicts of interest with respect to the authorship and/or publication of this article.

\section{Funding}

This study was supported by Scientific Research Projects Coordination Unit of Istanbul University (Project number 49091).

\section{REFERENCES}

1. World Health Organization, Cardiovascular diseases (CVDs). Available at: http://www.who.int/mediacentre/factsheets/ fs317/en/. [Accessed: November 10, 2017].

2. American Heart Association. New statistics show one of every three U.S. deaths caused by cardiovascular disease. Available at: http://newsroom.heart.org/news/new-statistics-show-oneof-every-three-u-s-deaths-caused-by-cardiovascular-disease. [Accessed: November 10, 2017].

3. Turkish Statistical Institute. Türkiye İstatistik Kurumu Ölüm Nedeni İstatistikleri. 2016, 24572. Available at: http://www. tuik.gov.tr/PreHaberBultenleri.do?id=24572. [Accessed: November 10, 2017].

4. Akar AR, Kurtcephe M, Sener E, Alhan C, Durdu S, Kunt $\mathrm{AG}$, et al. Validation of the EuroSCORE risk models in Turkish adult cardiac surgical population. Eur J Cardiothorac Surg 2011;40:730-5.

5. Okutan H, Yavuz T, Peker O, Tenekeci C, Düver H, Öcal A ve ark. Outcomes of Euroscore (European System for Cardiac Operative Risk Evaluation) at opareted patients in our clinic. Turk Gogus Kalp Dama 2002;10:201-5.

6. Geissler HJ, Hölzl P, Marohl S, Kuhn-Régnier F, Mehlhorn U, Südkamp M, et al. Risk stratification in heart surgery: comparison of six score systems. Eur J Cardiothorac Surg 2000;17:400-6.

7. Dişcigil B, Badak Mİ, Gürcün U, Boğa M, Özkısacık EA, Güneş TÜ. Açık Kalp Cerrahisi Sonuçlarının
Avrupa Kardiyak Risk Skorlama Sistemi (Euroscore) ile Değerlendirilmesi. ADÜ Tip Fakültesi Dergisi 2005;6:19-23.

8. Republic of Turkey Social Security Institution. Social Security Institution Declaration of Healthcare Implementation, (22.10.2014 Change Notification up-to-date 2013). Available at: http://www.sgk.gov.tr/wps/portal/sgk/tr/kurumsal/ merkez-teskilati/ana_hizmet_birimleri/gss_genel_ mudurlugu/anasayfa_duyurular/duyuru_20141022_03. [Accessed: November 10, 2017].

9. Karabulut H, Toraman F, Dağdelen S, Çamur G, Alhan C. EuroSCORE (European System for Cardiac Operative Risk Evaluation) risk skorlama sistemi gerçekçi mi? Türk Kardiyol Dern Arş 2001;29:364-7.

10. What is euroSCORE ? Available at: http://www.euroscore. org/what_is_euroscore.htm. [Accessed: November 10, 2017].

11. What is euroSCORE? (for patients). Available at: http://www. euroscore.org/patient.htm. [Accessed: November 10, 2017].

12. Nashef SA, Roques F, Michel P, Gauducheau E, Lemeshow S, Salamon R. European system for cardiac operative risk evaluation (EuroSCORE). Eur J Cardiothorac Surg 1999;16:9-13.

13. Roques F, Nashef SA, Michel P, Gauducheau E, de Vincentiis C, Baudet E, et al. Risk factors and outcome in European cardiac surgery: analysis of the EuroSCORE multinational database of 19030 patients. Eur J Cardiothorac Surg 1999;15:816-22.

14. Roques F, Gabrielle F, Michel P, De Vincentiis C, David M, Baudet E. Quality of care in adult heart surgery: proposal for a self-assessment approach based on a French multicenter study. Eur J Cardiothorac Surg 1995;9:433-9.

15. Roques F, Michel P, Goldstone AR, Nashef SA. The logistic EuroSCORE. Eur Heart J 2003;24:881-2.

16. EuroSCORE Project Group, EuroSCORE II. Available at: http://www.euroscore.org/calc.html. [Accessed: November 10, 2017].

17. Mitchell TM. Machine Learning. 1st ed. New York: McGrawHill; 1997.

18. Alpaydın E. Introduction to Machine Learning. Cambridge: MIT Press; 2014.

19. Simon HA, Why should machines learn?. In: Michalski RS, Carbonell JG, Mitchell TM, editors. Machine learning: An artificial intelligence approach. Berlin: Springer; 1984. p. 25-37.

20. Mohri M, Rostamizadeh A, Talwalkar A. Foundations of Machine Learning. London: The MIT Press; 2012.

21. Nouei MT, Kamyad AV, Sarzaeem M, Ghazalbash S. Developing a genetic fuzzy system for risk assessment of mortality after cardiac surgery. J Med Syst 2014;38:102.

22. Tu JV, Weinstein MC, McNeil BJ, Naylor CD. Predicting mortality after coronary artery bypass surgery: what do artificial neural networks learn? The Steering Committee of the Cardiac Care Network of Ontario. Med Decis Making 1998;18:229-35.

23. Lippmann RP, Kukolich L, Shahian D. Predicting the risk of complications in coronary artery bypass operations using neural networks. In: Tesauro G, Toretzky DS, Leen TK, editors. Advances in Neural Information Processing Systems 7. Cambridge: The MIT Press; 1995. p. 1055-62. 
24. Tunca A. Predicting Risk of Mortality in Patients Undergoing Cardiovascular Surgery. Master of Science Thesis, Ankara: Bilkent University; 2008.

25. Shearer C. The CRISP-DM model: the new blueprint for data mining. J Data Warehous 2000;5:13-22.

26. Additive/logistic EuroSCORE interactive calculator. Available at: http://euroscore.org/calc.html. [Accessed: November 10, 2017].

27. EuroSCORE for patients. Available at: http://www.euroscore. org/patienteuroscore2.html. [Accessed: November 10, 2017].

28. Han J, Kamber M. Data mining: concepts and techniques (the Morgan Kaufmann Series in data management systems). 2nd ed. California: Elsevier; 2006.

29. Özkan Y. Veri madenciliği yöntemleri. İstanbul: Papatya Yayıncılık Eğitim; 2008.

30. Balaban ME, Kartal E. Veri Madenciliği ve Makine Öğrenmesi Temel Algoritmaları ve R Dili ile Uygulamaları. 1. Bask1. İstanbul: Çağlayan Kitabevi; 2015.

31. Gan G. Data Clustering in C++: An Object-Oriented Approach. Florida: CRC Press; 2011.

32. Dekhtyar A. CSC 466: Knowledge Discovery from Data Distance/Similarity Measures. Available at: http://users.csc. calpoly.edu/ dekhtyar/560-Fall2009/lectures/lec09.466.pdf. [Accessed: November 10, 2017].

33. Karabulut E, Alpar R. Lojistik regresyon, In: Alpar R, editör. Uygulamalı Çok Değişkenli İstatistiksel Yöntemler. Ankara: Detay Yayıncılık; 2011. s. 591-660.

34. Sokolova M., Lapalme G. A Systematic analysis of performance measures for classification tasks. Inf Proc Manage 2009;45:427-37.
35. R-project, The R Project for Statistical Computing. Available at: http://www.r-project.org/. [Accessed: November 10, 2017].

36. RStudio, Take control of your R code. Available at: https:// www.rstudio.com/products/rstudio/. [Accessed: November 10, 2017].

37. Meyer D, Dimitriadou E, Hornik K, Weingessel A, Leisch F. e1071: Misc Functions of the Department of Statistics (e1071), TU Wien, 2017, Available at: https://CRAN.Rproject.org/package=e1071. [Accessed: November 10, 2017].

38. Wei B, Yang F, Wang X, Ge Y. knnGarden: Multi-distance based k-Nearest Neighbors, 2012, Available at: https:// CRAN.R-project.org/package $=\mathrm{knnGarden.} \mathrm{[Accessed:}$ November 10, 2017].

39. Hornik K, Buchta C, Zeileis A. Open-source machine learning: R meets weka. Comput Stat 2009;24:225-32.

40. Witten IH, Frank E. Data Mining: Practical machine learning tools and techniques. 2nd ed. San Francisco: Morgan Kaufmann; 2005.

41. Chang W, Cheng J, Allaire JJ, Xie Y, McPherson J. Shiny: Web Application Framework for R. 2017. Available at: https:// CRAN.R-project.org/package=shiny. [Accessed: November 10, 2017].

42. Chang W. Shinythemes: Themes for Shiny. 2016, Available at: https://CRAN.R-project.org/package=shinythemes. [Accessed: November 10, 2017].

43. RStudio. Shiny. Available at: https://shiny.rstudio.com/. [Accessed: November 10, 2017].

44. RStudio. shinyapps.io. Available at: http://www.shinyapps.io/. [Accessed: November 10, 2017]. 